\title{
PHYTOCHEMISTRY SCREENING AND GAS CHROMATOGRAPHY-MASS SPECTROMETRY ANALYSIS OF BIOACTIVE COMPOUNDS PRESENT IN KARO TRADITIONAL OIL, AN INDONESIAN TRADITIONAL HERBAL MEDICINE
}

\author{
NOVA PRIMADINA ${ }^{1,2 *}$, ACHMAD BASORI ${ }^{3}$, DAVID S PERDANAKUSUMA ${ }^{4}$ \\ ${ }^{1}$ Doctoral Program, Faculty of Medicine, Airlangga University, Surabaya, Indonesia. ${ }^{2}$ Department of Surgery, Faculty of Medicine, \\ Muhammadiyah Surabaya University, Jawa Timur, Indonesia. ${ }^{3}$ Department of Pharmacology, Airlangga University, Surabaya, Indonesia. \\ ${ }^{4}$ Department of Plastic Surgery, Airlangga University, Dr. Soetomo Hospital, Surabaya, Indonesia. Email: novaprimadina@fk.um-surabaya.ac.id \\ Received: 28 December 2019, Revised and Accepted: 02 January 2020
}

ABSTRACT

Objective: The purpose of this research was to observe the bioactive compounds of Karo traditional oil by phytochemistry screening and gas chromatography-mass spectrometry (GC-MS) analysis.

Method: We use $150 \mathrm{mg}$ sample of traditional Karo traditional oil, methanol, ethanol, Dragendorff reagent, acetic acid anhydride, sulfuric acid, $\mathrm{HCl}$, magnesium powder, FeCL3 1\%, KLT plates, test tubes, dropper pipette, porcelain cup, filter paper, and a boiler.

Results: Alkaloid, terpenoid and flavonoid compounds were found, and no polyphenol compound from phytochemistry screening and 16 constituents were identified from the GC-MS analysis, $\alpha$-pinene was found as the major component (74.47\%), delta-3-carene (9.62\%), 1\% of octane, dodecane, camphor, undecane, isodecane, sabinene, hexadecane, nonane, and $<1 \%$ tridecane, cyclohexane, pentacosane, heptadecan, limonene, and camphene.

Conclusion: Karo traditional oil works as a potent anti-inflammation at the inflammation phase of the wound healing process by suppressing the pro-inflammatory cytokines and promote anti-inflammatory cytokines.

Keywords: Traditional medicine, Indonesia traditional medicine, Phytochemistry screening, Gas chromatography-mass spectrometry, Karo oil, Karo traditional oil, Wound healing.

(c) 2020 The Authors. Published by Innovare Academic Sciences Pvt Ltd. This is an open access article under the CC BY license (http://creativecommons. org/licenses/by/4. 0/) DOI: http://dx.doi.org/10.22159/ajpcr.2020.v13i2.36736

\section{INTRODUCTION}

A tropical country like Indonesia has a huge nature potential to be explored, which is the use of plants for medicine purposes. The regions in Indonesia have many traditional ingredients to maintain health or cure various diseases; more than 2000 types of medicinal plants grow and develop in Indonesia. However, only 1000 types only those that have been recorded, and around 300 types have been used for traditional medicine [1,2]. Indonesian government has partitioned the planning of restorative plants into three classes, for example, jamu, institutionalized natural meds, and fitofarmaka (phytomedicines) [3]. One of them is located in North Sumatra. Quick healing is often found to occur on open wounds smeared with traditional oil from Karo or also known by the name of, but its mechanism of action cannot yet be explained. Traditional oil from Karonese tribe or better known as Karo traditional oil is the traditional oil mixed artificially from herbs by Karonese tribe from North Sumatera and it is well known for its benefits and used long ago for generations among the people of North Sumatra. The common people already use Karo traditional oil from Karonese tribe for the treatment of fracture, burns and wounds, removing lumbago, arthritis, colds and bloating, treat sprains (whiplash), itching, stung by venomous animals $[4,5]$. The average said that the fractures healed, and wounds healed faster than usual, and pain relieved faster compared to the treatment of wounds using common medications, but these phenomena have not yet to be explained. Even the contents of Karo traditional oil itself and its mechanism of action have never been examined to date [4-6].

Karo traditional oil is made from $100 \%$ natural ingredients and has a long shelf life even without additional chemicals ingredients, making it more environmentally friendly and have minimal side effects [6]. It was proven that the Karo traditional oil already meet the standards quality as ingredients that are used in a way smeared on the skin according to Indonesia National Agency of Drug and Food Control number HK.03.1.23.07.11.6662 in 2011 [6]. The content of the metal is still below the threshold for medicine and food, to where the concentration is not more than $15 \mathrm{mg} / \mathrm{kg}$ for $\mathrm{Cu}$ and $10 \mathrm{mg} / \mathrm{kg}$ for $\mathrm{Pb}$ and $30 \mathrm{mg} / \mathrm{kg}$ for Fe [6].

Empirical data obtained from the study of Karo traditional oil, 90 people out of 140 respondents who have used Karo traditional oil, $70.3 \%$ is used for curative purposes (treatment), the rest of it as much as 14.8\% for the purpose of promotion, $12.5 \%$ for the preventive purposes and 2 , and $4 \%$ for rehabilitative purposes. Most of them are satisfied with the result, only $0.7 \%$ said do not get results as expected. Among 70.3\% (63 respondents) who use Karonese traditional oil for curative purposes, $42.86 \%$ (27 respondents) use it for wound treatment [1].

Preliminary study has been done using this Karo traditional oil for wound healing compared with moist wound care, and the result shows that Karo traditional oil can accelerate the wound re-epithelialization in day $7^{\text {th }}$ after initial treatment like shown in these pictures below Fig. 1 .

Based on the data above, we try to investigate and describe the constituents of the Karonese traditional oil which have not been studied previously by phytochemistry screening and gas chromatographymass spectrometry (GC-MS) analysis. Phytochemical screening is a test for identifying the active medicinal substances found in plants. By finding the bioactive compounds of Karo traditional oil from these examinations, we will do additional research about each compound combination effect on the wound healing process and will find out which compound do the accelerating effect of the wound healing process, its therapeutic effects and mechanism of action. 


\section{METHODS}

\section{Phytochemistry screening}

In phytochemistry screening, we use $150 \mathrm{mg}$ sample of traditional Karo traditional oil, methanol, ethanol, Dragendorff reagent, acetic acid anhydride, sulfuric acid, $\mathrm{HCl}$, magnesium powder, $\mathrm{FeCL}_{3} 1 \%$, KLT plates, test tubes, dropper pipette, porcelain cup, filter paper, and a boiler.

In alkaloid compound analysis, Karo traditional oil was diluted in $4 \mathrm{ml}$ methanol and dropped $5 \mu \mathrm{m}$ on KLT plate, and Dragendorff reagent dropped to the KLT plate. In terpenoid and steroid compound analysis, 50-100 mg Karo traditional oil sample is placed on the plate and dropped with acetic acid anhydride, left for about $15 \mathrm{~min}$. Then, six drops of solution are transferred to the test tube and added 2-3 drops of concentrated sulfuric acid. The presence of a triterpenoid is indicated by the occurrence of orange or purple-red, while the presence of steroids is indicated by the presence of blue. In flavonoid compound analysis, $200 \mathrm{mg}$ of plant samples were extracted with $5 \mathrm{ml}$ ethanol and heated for $5 \mathrm{~min}$ in a test tube. Then, add a few drops of concentrated $\mathrm{HCl}$. Then, $0.2 \mathrm{~g}$ of magnesium powder is added. Positive results are indicated by the appearance of dark red (magenta) in $3 \mathrm{~min}$. Analysis of saponin composition: Two grams of Karo traditional oil are put into a test tube so that the complete examination is submerged, boiled for 2-3 min, and then cooled, then shaken vigorously. Positive results are collected by the formation of a stable foam. Analysis of tannin composition: A total of 20 mg of traditional Karo traditional oil, plus ethanol until all samples are submerged. Then, $1 \mathrm{ml}$ of the solution is transferred into the test tube, and 2-3 drops of $1 \% \mathrm{FeCl}_{3}$ solution are added. Positive results are considered with the formation of a black or green-bluish color.

\section{GC-MS analysis}

GC-MS analysis was performed on GC-MS Agilent technologies 6890N Network GC system, chromatography column Agilent 19091J-413 HP-S $30 \mathrm{~m} 0.32 \mathrm{~mm}$ ID (0.25 umdf) capillary, and Agilent technologies 5973 inert mass selective detector. The temperature program in profiling was $50^{\circ} \mathrm{C}$ in $5 \mathrm{~min}$, then $280^{\circ}$ in $5 \mathrm{~min}$, at $10^{\circ} \mathrm{C} / \mathrm{min}$. The carrier gas was helium $0.5 \mathrm{ml} / \mathrm{min}$, the injector and detector temperatures were $250^{\circ} \mathrm{C}$, injection of $10 \mathrm{ml}$ hexane solution $10 \%$.

The sample is extracted with $3 \mathrm{ml}$ hexane, then poured into derivatization chamber and nitrogen is added. $2 \mathrm{ml} \mathrm{NaOH} 2 \%$ in methanol is added and then the solution is heated in $5 \mathrm{~min} . \mathrm{BF}_{3}$ in methanol is added then the solution is heated to $90^{\circ} \mathrm{C}$ within $30 \mathrm{~min}$. Finally, $3 \mathrm{ml}$ hexane is added and then vortex the solution for extraction. After all, let the solution stands until separated into two-phase. Take the upper phase to be injected into the GC-MS.

\section{RESULTS}

Phytochemistry screening result

In phytochemistry screening like shown on Table 1 , we found that Karo traditional oil form is oil or viscous liquid with green color, its smell of typical nutmeg aroma oil and feels sticky on hand. The alkaloid screening result is positive, its reacted with the Dragendorff reagent formed orange, red sediment which is shown in Fig. 2a. Its terpenoid result is positive; there was a purple, red stain on the KLT plate which is shown in Fig. $2 \mathrm{~b}$. The flavonoid screening result with thin-layer chromatography method is positive, with a yellow stain on the KLT plate which is shown in Fig. 2c. The polyphenol and tannin screening results are negative because there was no blackish-brown stain on the KLT plate which is shown in Fig. $2 \mathrm{~d}$ and e, and the saponin screening result is negative with no foam on the water surface which is shown in Fig. 2f.

\section{GC-MS analysis result}

In GC-MS screening test like shown on Table 2.

\section{DISCUSSION}

The recipe of traditional Karo oil comes from a mixture of 51 Indonesian family medicinal plants (TOGA plants) $[4,6,7]$, some of them are leaves and the roots of Piper betle, Cymbopogon nardus, Avicennia marina, Solanum verbacifolium, Sonchus arvensis', Kaempferia galangal L., Drymoglossum piloselloides L., Clerodendrum sp., Plantago major L. imperata, Orthosiphon spicatus B.B.S., Strobilanthes crispa, Vitex trifolia L., Gynura procumbens, Gynura segetum, Vitis gracilis bl., Chromolaena odorata, Zingiber officinale Rosc., Pluchea indica, Areca catechu, Myristica fragrans, Piper nigrum, Zingiber purpureum Roxb., Kaempferia galanga, Bambusa vulgaris Schard, Ulmus lancaefolia, Curcuma domestica Val, Imperata cylindrica, Macodes petola BL., Arenga pinnata, Ocimum citriodorum Vis., Allium cepa, Allium sativum, Boehmeria nivea, Citrus hystrix, and Usnea barbara fries. All of these medicinal plants were cut and boiled with Green Coconut Oil (Cocos nucifera linn) and cooking oil for $9 \mathrm{~h}$ on the small firewood $[4,8]$.

The phytochemical screening method is carried out by looking at the color testing reaction using a color reagent. The reasons to do phytochemical screening are to reveal the potential of plant resources
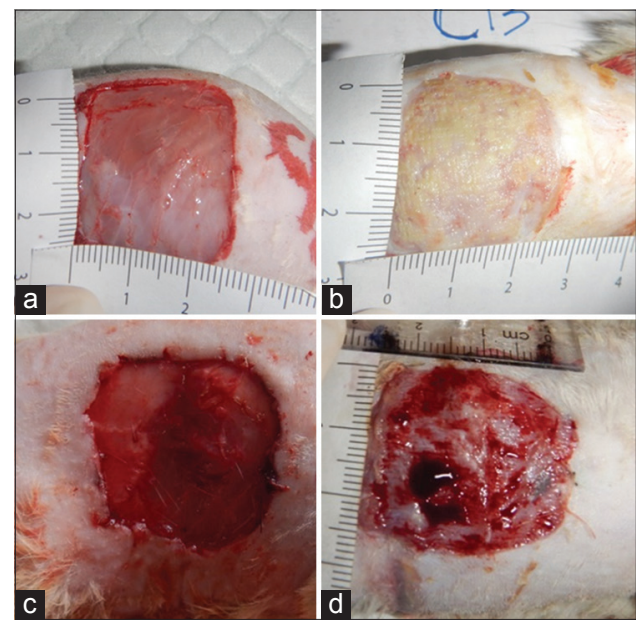

Fig. 1: (a) Full-thickness wound on Wistar norvegicus back day 0 treated by traditional Karo traditional oil, (b) wound day 7 treated by Karo traditional oil already full re-epithelialization, (c) full-thickness wound on Wistar norvegicus back day 0 treated by moist gauge, (d) wound day 7 treated by moist gauge still shows inflammation signs

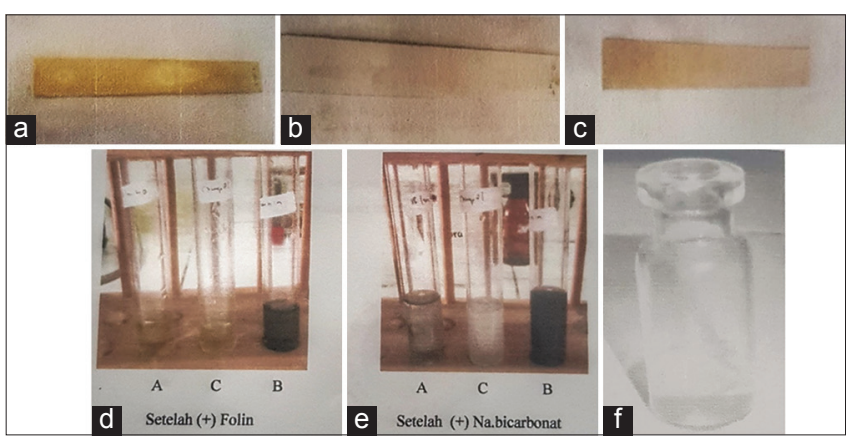

Fig. 2: (a) Positive alkaloid test result, (b) positive terpenoid test result, (c) positive flavonoid test result, (d) negative polyphenol test result, (e) negative tannin test result, (f) negative saponin

Table 1: Karo traditional oil's contents based on gas chromatography-mass spectrometry test result

\begin{tabular}{llll}
\hline Compound & Result & Compound & Result \\
\hline Alkaloid & $(+)$ & Polyphenol & $(-)$ \\
Monoterpene & $(+)$ & Tannin & $(-)$ \\
Flavonoid & $(+)$ & Saponin & $(-)$ \\
\hline
\end{tabular}


Table 2: Karo traditional oil 's contents based on gas chromatography-mass spectrometry test result

\begin{tabular}{|c|c|c|c|c|c|}
\hline Compound & Percentage & Molecular formula & Molecular weight $(\mathrm{g} / \mathrm{mol})$ & Peak area $(\%)$ & 3D structure \\
\hline Alpha-pinene & 74.47 & $\mathrm{C}_{10} \mathrm{H}_{16}$ & 136.23 & 72.13 & \\
\hline Delta-3-carene & 9.62 & $\mathrm{C}_{10} \mathrm{H}_{16}$ & 136.23 & 9.32 & \\
\hline Dodecane & 1.776 & $\mathrm{C}_{12} \mathrm{H}_{26}$ & 170.33 & 1.72 & \\
\hline Camphor & 1.766 & $\mathrm{C}_{10} \mathrm{H}_{16} \mathrm{O}$ & 152.23 & 1.71 & \\
\hline Undecane & 1.162 & $\mathrm{C}_{11} \mathrm{H}_{24}$ & 156.31 & 1.13 & \\
\hline Isodecane & 1.093 & $\mathrm{C}_{10} \mathrm{H}_{22}$ & 142.28 & 1.06 & \\
\hline Sabinene/thujene & 1.061 & $\mathrm{C}_{10} \mathrm{H}_{16}$ & 136.23 & 1.03 & \\
\hline $\begin{array}{l}\text { Hexadecane } \\
\text { Nonane }\end{array}$ & $\begin{array}{l}1.023 \\
1.012\end{array}$ & $\begin{array}{l}\mathrm{C}_{11} \mathrm{H}_{24} \\
\mathrm{C}_{9} \mathrm{H}_{20}\end{array}$ & $\begin{array}{l}226.44 \\
128.25\end{array}$ & $\begin{array}{l}0.99 \\
0.98\end{array}$ & \\
\hline Tridecane & $\begin{array}{l}0.992 \\
0.886\end{array}$ & $\begin{array}{l}\mathrm{C}_{13} \mathrm{H}_{28} \\
\mathrm{C} \mathrm{H}\end{array}$ & $\begin{array}{l}184.36 \\
84.16\end{array}$ & $\begin{array}{l}0.96 \\
0.86\end{array}$ & \\
\hline $\begin{array}{l}\text { Pentacosane } \\
\text { Heptadecan }\end{array}$ & $\begin{array}{l}0.878 \\
0.870\end{array}$ & $\begin{array}{l}\mathrm{C}_{25} \mathrm{H}_{52} \\
\mathrm{C}_{18} \mathrm{H}_{38}\end{array}$ & $\begin{array}{l}352.7 \\
254.5\end{array}$ & $\begin{array}{l}0.85 \\
0.84\end{array}$ & \\
\hline Limonene & 0.840 & $\mathrm{C}_{10} \mathrm{H}_{16}$ & 136.23 & 0.81 & \\
\hline Camphene & 0.738 & $\mathrm{C}_{10} \mathrm{H}_{16}$ & 136.23 & 0.71 & \\
\hline
\end{tabular}


and determine the characteristics of active compounds that cause toxic effects or beneficial effects, which are shown by the effects of coarse plants when tested with biological systems. The important thing that plays an important role in the phytochemical ring is the selection of solvents and extraction methods [9].

Alkaloids are secondary or tertiary or sometime quartery nitrogen atom compounds found in plants. They are found in the form of water-soluble salts such as citrate, malate, meconate, tartrate, isobutyrate, benzoate, or sometimes in combination with tannins in plants. Microchemical, alkaloids were found in many peripheral tissues of the stem or roots and synthesized in specific locations such as growing roots, chloroplasts, and lactiferous cells [10]. Mayer or Dragendorff solutions are the reactors which are used to identify alkaloid compounds in a sample.

Terpenoids are a natural compound formed by biosynthetic processes, widely distributed in the cytoplasm of plant cells. They are found not only in higher plants but also in coral reefs and microbes. The terpenoid structure is fat-soluble and constructed by isoprene molecules, terpenoid skeletons are formed from two or more units of isoprene units. In this research, terpenoids are the dominant secondary metabolite in Karo traditional oil, which make it a potent antiinflammatory medicine [11-14].

Flavonoids, a group of naturally occurring benzo- $\gamma$-derivatives, are a compound found synthesized by vascular plants in response to microbial infection [2], binds with glucoside and flavonoid aglycone, which have abilities to show various biological properties such as antioxidant, antibacterial, anti-inflammatory, and antiviral effects [15]. To identify the flavonoid compound, the aglycones in plant extracts that have been hydrolyzed are examined. The extraction process is carried out with boiling ethanol to avoid oxidation. Karo traditional oil has flavonoids compound; they inhibit lipid peroxidation which occurs in injury therefore shown an increasing collagen fiber's strength by increasing the angiogenesis in the wound healing process and preventing cell damage [15]. Flavonoids in Karo traditional oil scavenge the reactive oxygen species and free radicals to prevent the oxidative stress $[2,15]$

The polyphenol phytochemistry screening is done to identify the secondary metabolite of Karo traditional oil using $\mathrm{FeCl} 3$ as the reactor. A positive result will be shown green, red, blue, purple, or black strong color. Karo traditional oil does not have any polyphenol secondary metabolite because there is no phenolic reaction's color appear in the middle test tube.

Saponin is a glucoside which dissolves in water and has bubble when shaking in the water with Liebermann-Burchard reactor. It has high toxicity and the ability to lysis the red blood cell. There are two kinds of saponin based on its structures, steroid frameworks saponin and triterpenoid framework saponin. Karo traditional oil does not have any saponin compound in it so it is not toxic and safe to use in wound care.

Alpha pinene was found to be the major component of Karo traditional oil, together with $\delta$-3carene, sabinene, limonene, and camphene are monoterpenic compounds which have an anti-inflammatory, antibacterial and fungal, antioxidant, and anti-hypernociceptive [11,12]. Alpha pinene also has the strongest immunostimulation activity and potential immunomodulating effects on natural killer cell activity and lymphocyte activation through CD 69 expression among all compounds [12]. A research from Kang et al. shows that alphapinene inhibits tumor invasion through tumor necrosis factor (TNF)- $\alpha$ inhibition and downregulation of NF- $\kappa \beta$-regulated matrix metalloproteinase-9 gene expression in human breast cancer cells in a dose-dependent manner [13]. This result suggests that Karo traditional oil may potentially be developed into an anti-metastatic drug. Alphapinene together with limonene also inhibits the leukotriene production as a mediator of inflammation; this indicates that Karo traditional oil can be used for variety of inflammatory diseases [12]. Alpha-pinene stimulates the inflammatory cell production, macrophage type-2 which is the key regulation of the wound healing process, but in the same time it suppresses the neutrophil migration, production of macrophage type-1 and pro-inflammatory cytokines, by blocking tolllike receptor-4 receptor which should be bound by DAMP and PAMP compound to stimulate the release of pro-inflammatory cytokines, this inhibits the NF- $\kappa \beta$, I $\kappa$ B kinase- $\beta$, and caspase- 1 activation and suppress the MAPK pathway through decreasing of MAPK phosphorylation (ERK and JNK) in inflammatory cells and reduce the pro-inflammatory mediators such as interleukin-6, TNF- $\alpha$, and cyclooxygenase-2 expression $[11,13,14,16,17]$. Alpha-pinene and other terpene compounds in Karo traditional oil play an important step in the inflammatory phase in wound healing [11]

C. nucifera oil is the solvent of Karo traditional oil; it also useful in wound healing treatment because of its short-chained and saturated fatty acids which prevent it from become rancid and suitable for the preservation of Karo traditional oil's bioactive compounds and for wound treatment [2]

Its effect on the proliferation and remodeling phase remains unknown [13]. Therefore, it is necessary to do additional research to find the mechanism of action of this Karo traditional oil in the phase of proliferation and remodeling, which accelerates the re-epithelialization process.

\section{CONCLUSION}

Karo traditional oil contains terpene, alkaloid, and flavonoid compounds. Alpha-pinene was found to be the major component of Karo traditional oil, followed by delta-3-carene, octane, dodecane, camphor, undecane, isodecane, sabinene, hexadecane, nonane, tridecane, cyclohexane, pentacosane, heptadecan, limonene, and camphene.

Wound healing was accelerated by Karo traditional oil by suppressing the pro-inflammatory cytokines and promote anti-inflammatory cytokines, Karo traditional oil works as a potent anti-inflammation which regulates the inflammation phase of the wound healing process. Its effect on the proliferation and remodeling phase remains unknown. Therefore, it is necessary to do additional research to find the mechanism of action of this Karo traditional oil in the phase of proliferation and remodeling, which accelerates the re-epithelialization process.

\section{AUTHORS CONTRIBUTION AND FUNDING}

This work by the authors was funded by the University of Muhammadiyah Surabaya and supported by the Faculty of Veterinary Medicine Airlangga University Surabaya.

\section{CONFLICTS OF INTEREST}

The authors whose names are listed in this article certify that they have no affiliations with or involvement in any organization or entity with any financial interesting the subject matter or materials discussed in this manuscript.

\section{REFERENCES}

1. Utami UD. Comparison of quality of karo oil produced by CV. In: Fruits and Refining Methods. Medan: North Sumatera University; 2018.

2. Soni H, Singhai AK. A recent update of botanical for wound healing activity. Int Res J Pharm 2012;3:1-7.

3. Woerdenbag HJ, Kayser O. Jamu: Indonesian traditional herbal medicine towards rational phytopharmacological use. J Herb Med 2014;4:51-73.

4. Barus LP. Karo massage oil making ritual in Juma Padang village Barusjahe karo district Buddayah. J Pendidikan Antropologi 2017; $1: 176-9$

5. SitepuW.TraditionaloilfromTanahKaro.Kompasiana;2015.Availablefrom: https://www.kompasiana.com/Minyakkaro/54f8513ba333112e1f8b55c4/ minak-pengalun-ramuan-minyak-tradisional-dari-tanah-karo. [Last 
accessed on 2014 Feb 21]; [Last accessed 2016 Apr].

6. Nababan RT. Analysis of $\mathrm{Cu}, \mathrm{Fe}$, and $\mathrm{Pb}$ Metal Content in Traditional Karo Oil. Medan: North Sumatera University; 2014. Available from: https://www.repository.usu.ac.id/handle/123456789/40567. [Last accessed on $2016 \mathrm{Aug}]$.

7. Sembiring R, Utomob B, Batubara R. Vegetation diversity of medicinal plants in the educational forest of the university of North Sumatra, Taman Hutan Raya Tongkoh, Karo Regency, North Sumatra. Peronema For Sci J 2013;2:19-22.

8. Pazyar N, Yaghoobi R, Rafiee E, Mehrabian A, Feily A. Skin wound healing and phytomedicine: A review. Skin Pharmacol Physiol 2014;27:303-10.

9. Pramudya WA. Structural Elucidation of Isolates Resulting from the Chloroform Extract of the Skin of Gowok Plant (Syzygius polycephalum) and Antioxidant Activity Test. Negeri: Mathematics and Science Faculty of Negeri Surabaya University; 2016.

10. Ammar GA. Alkaloid Test. Bandung: Faculty of Math and Science, Bandung Institute of Technology, Department OC; 2014.

11. Kummer R, Estevão-Silva CF, Bastos RL, Rocha BA, Spironello RA, Yamada AN, et al. Alpha-pinene reduces in vitro and in vivo leukocyte migration during acute inflammation. Int $\mathrm{J}$ Appl Res Nat Prod 2015;8:12-7
12. de Cassia da Silveira e Sa R, Andrade LN, de Sousa DP. A review on antiinflammatory activity of monoterpenes. Molecules 2013;18:1227-54.

13. Kang E, Lee DH, Jung YJ, Shin SY, Koh D, Lee YH. $\alpha$-pinene inhibits tumor invasion through downregulation of nuclear factor (NF)- $\kappa$ B-regulated matrix metalloproteinase- 9 gene expression in MDA-MB-231 human breast cancer cells. Appl Biol Chem 2016;59: 511-516.

14. Kim DS, Lee HJ, Jeon YD, Han YH, Kee JY, Kim HJ, et al. Alphapinene exhibits anti-inflammatory activity through the suppression of MAPKs and the NF-kappaB pathway in mouse peritoneal macrophages. Am J Chin Med 2015;43:731-42.

15. Patil N, Vaishnav RL, Thanusubramanian H, Holla SN, Manohar HD, Bairy KL. Formulation and evaluation of the hydroalcoholic extract of Caesalpinia pulcherrima (Stem bark) on wound healing model in Wistar rats. Int J Adv Res 2015;3:648-54.

16. Krzyszczyk P, Schloss R, Palmer A, Berthiaume F. The role of macrophages in acute and chronic wound healing and interventions to promote pro-wound healing phenotypes. Front Physiol 2018;9:419.

17. Rufino AT, Ribeiro M, Judas F, Salgueiro L, Lopes MC, Cavaleiro C, et al. Anti-inflammatory and chondroprotective activity of (+)-alpha-pinene: Structural and enantiomeric selectivity. J Nat Prod 2014;77:264-9. 